\title{
PHYTOCHEMICAL SCREENING, ANTIOXIDANT AND ANTIBACTERIAL ACTIVITIES OF MILLINGTONIA HORTENSIS (L)
}

\author{
JANAKI A., KALEENA P. K. , ELUMALAI D., HEMALATHA P., BABU M., VELU K., SUDHA RAVI \\ Department of Zoology, Presidency College (Autonomous), Chennai-05, Tamilnadu, India \\ Email: drpkklab@gmail.com
}

Received: 21 May 2017, Revised and Accepted: 22 Jul 2017

\begin{abstract}
Objective: Millingtonia hortensis Linn (Bignoniaceae) is commonly known as cork tree and Akash neem. Aim of studies to determine the antioxidant activity and antibacterial activity.
\end{abstract}

Methods: The antioxidant activity of different solvent extracts were measured by chemical analyses involving the assay of 1,1-diphenyl-2picryhydrazyl (DPPH) radical scavenging activity and super oxide radical scavenging activity.

Results: Phytochemicals (secondary metabolites) screening of methanol, chloroform, ethanol, petroleum ether, aqueous leaf extracts revealed the presence of carbohydrates, tannins, saponins, flavonoids, alkaloids, betacyanins, phenols and coumarins.

Conclusion: The presence of these phytochemicals and antioxidant capacity support the use of this plant as an antibacterial agent against the group of micro organisms tested.

Keywords: Millingtonia hortensis, Phyto compounds, Antioxidant activity, GC-MS analysis, Anti bacterial activity

(C) 2017 The Authors. Published by Innovare Academic Sciences Pvt Ltd. This is an open access article under the CC BY license (http://creativecommons.org/licenses/by/4.0/) DOI: http://dx.doi.org/10.22159/ijcpr.2017v9i5.2217

\section{INTRODUCTION}

Medicinal plants play a key role in healthcare and about $80 \%$ of the world's populations rely on the use of traditional medicine $[1,2]$. Phytochemicals are primary and secondary metabolites of plants which fight to protect our health against diseases. Phytocompounds commonly found in plants have been reported to have multiple biological effects including antioxidant activity. In recent years, secondary plant metabolites (phytochemical) previously with unknown pharmacological activities have been extensively investigated as a source of medicinal agents [3]. The secondary metabolites like phenolics and flavonoids from plants have been reported to be potent free radical scavengers and thus act as antioxidants [4].

Antioxidants reduce the oxidative stress in cells and are therefore useful in the treatment of many human diseases including cancer, cardiovascular diseases and inflammatory diseases. It is believed that high intake of antioxidant-rich food is associated with decreased risk of degenerative diseases, particularly cardio vascular diseases and cancer [5]. The synthetic antioxidants (e. g) butylated hydroxyl anisole (BHA) butylated hydroxyl toluene (BHT) or vitamin E [6-8] are commonly used. These synthetic antioxidants such as butylated hydroxyl anisole (BHA) butylated hydroxyl toluene (BHT) etc. may have carcinogenic and other harmful effects on the lungs and liver [9-11] of human beings. Scientists have continuously engaged in the search for naturally occurring potential and non-toxic antioxidants which could prevent free radical related disorders in human beings and also can replace the harmful synthetic antioxidants [9-11].

Plant derived antioxidants have advantages as they are less toxic and more effective and economical and hence there is a growing interest in identifying natural antioxidants of plant origin [12]. The search for cheap and abundant sources of natural antioxidants is attracting worldwide interest.

The drugs already in use to treat the infectious disease are of concern because drug safety remains an enormous global issue. Most of the synthetic drugs cause side effects and also most of the microbes have developed resistance against the synthetic drugs [13]. To alleviate this problem, antimicrobial compounds from potential plants should be explored. These drugs from plants are less toxic, side effects are scanty and also cost effective. They are effective in the treatment of infectious diseases while simultaneously mitigating many of the side effects that are often associated with synthetic antimicrobials [14].

Plant based antimicrobials represent a vast untapped source of medicines and further exploration of plant antimicrobials is the need of the hour. Antimicrobials of plant origin have enormous therapeutic potential. Plant-derived antimicrobials have a long history of providing the much-needed novel therapeutics [15]. Plants constantly interact with the rapidly changing and potentially damaging external environmental factors. Being organisms devoid of mobility, plants have evolved elaborate alternative defence strategies, which involve an enormous variety of chemical metabolites as tools to overcome stress conditions.

Millingtonia hortensis Linn is an important medicinal plant, found throughout South Asia and is well known for its fragrant flowers. The leaves of $M$. hortensis are used as antipyretic, sinusitis, cholagogue and tonic in folklore medicine [16] and is a rich source of essential oil, flavonoids, tannin and alkaloids [17].

\section{MATERIALS AND METHODS}

\section{Preparation of plant extract}

Millingtonia hortensis leaves were collected and authenticated by Prof. P. Jayaraman, Plant Anatomy Research Centre (Voucher No: PARC/2015/3058), West Tamabaram, Chennai-45. Leaves dried under shade at room temperature for about $20 \mathrm{~d}$. The dried leaves were powdered and sieved to get fine powder using an electric blender. $70 \mathrm{~g}$ of the powder was filled in the thimble and extracted successively with methanol, petroleum ether, chloroform, ethanol, using soxhlet extractor for $10 \mathrm{~h}$. All the extracts were concentrated using rotary flash evaporator and preserved at $4{ }^{\circ} \mathrm{C}$ in an airtight bottle until further use. (fig. 1)

\section{Phytochemicals screening}

The phytochemical screening was carried out using standard procedures. [18] By this analysis, the presence of several phytochemicals listed in (table 1) were tested. 


\section{Antioxidant assay}

\section{DPPH method}

The 1, 1-diphenyl-2-picrylhydrazine (DPPH) radical scavenging assay was first described by [19] and was later modified slightly by numerous researchers. It is one of the most extensively used antioxidant assays for plant samples. DPPH is a stable free radical that reacts with compounds that can donate a hydrogen atom. This method is based on the scavenging of DPPH through the addition of a radical species or an antioxidant that decolourizes the DPPH solution. The antioxidant activity is then measured by the decrease in absorption at $515 \mathrm{~nm}$. In this method, a $0.1 \mathrm{mmol}$ solution of DPPH in methanol is prepared, and $4 \mathrm{ml}$ of this solution are added to $1 \mathrm{ml}$ of the sample solution in methanol at varying concentrations. Thirty minutes later, the absorbance was measured at $517 \mathrm{~nm}$. A large decrease in the absorbance of the reaction mixture indicates significant free radical scavenging activity of the compound.

\section{Superoxide radical scavenging assay}

The superoxide anion radicals are produced in $2 \mathrm{ml}$ of phosphate buffer (100 mmol, pH 7.4) with $78 \mu \mathrm{M}$-nicotinamide adenine dinucleotide (NADH), $50 \mu \mathrm{M}$ nitro blue tetrazolium chloride (NBT) and test samples at different concentrations. The reaction mixture is kept for incubation at room temperature for $5 \mathrm{~min}$. It is then added with 5-methylphenazinium methosulphate (PMS) $(10 \mu \mathrm{M})$ to initiate the reaction and incubated for $5 \mathrm{~min}$ at room temperature. The colour reaction between superoxide anion radical and NBT is read at $560 \mathrm{~nm}$. Gallic acid is used as a positive control agent for comparative analysis. The reaction mixture without test sample is used as a control and without PMS is used as blank [20]. The scavenging activity is calculated as follows,

A) $\%$ Scavenging activity $=[($ Control OD-Sample OD $) /$ Control OD $] \times 100$

\section{GC-MS analysis}

GC-MS analysis were carried out an SHIMADZU QP 2010T which comprised of an auto sampler and gas chromatography interfaced to a mass spectrometer (GC-MS) instrument employing the following condition: capillary column $-624 \mathrm{~ms}(30 \mathrm{~m} \times 0.32 \mathrm{~mm} \times 1.8 \mathrm{~m})$ operating in an electron mode at $70 \mathrm{eV}$; helium (99.999\%) was used as carrier gas at a constant flow of $1.491 \mathrm{ml} / \mathrm{min}$ and injection volume of $1.0 \mathrm{ml}$, injector temperature was $140{ }^{\circ} \mathrm{C}$; ion source temperature of $200{ }^{\circ} \mathrm{C}$. The oven temperature was programmed from $45^{\circ} \mathrm{C}$. Mass spectra were taken at $70 \mathrm{eV}$.

\section{GC-MS identification of compounds}

Interpretation of mass spectrum GC-MS was conducted using a database of National Institute Standard and technology having more than 62,000 patterns. The spectrum of the unknown compounds stored in the NIST library. The compound prediction was based on Dr. Duke's Phytochemical and ethnobotanical database by Dr. Jim Duke of the agricultural research service/USDA. The names of the components of the test material were ascertained.

\section{Antimicrobial assay}

\section{Micro organisms}

All microbial strains were provided from the microbiology department, Presidency College, Chennai-05. Bacterial strains were maintained by subculture on nutrient agar favourable to their growth for $24 \mathrm{~h}$ in the dark at $37^{\circ} \mathrm{C}$. The antibacterial activity was evaluated using Escherichia coli, Klebsiella pneumonia, Pseudomonas aeroginosa, Salmonella typhi, Citrobacter braakii.

\section{Antibacterial assay}

The antimicrobial activity of the extracts was determined by disc diffusion method with minor modifications which is based on the spread of antimicrobial compound in the solid medium [21,22]. The Mueller-Hinton agar was poured in sterile Petri dishes $(90 \mathrm{~mm}$ diameter). The paper discs (6 $\mathrm{mm}$ diameter) that were impregnated with ethanolic extract $10,15,20,25,30 \mu \mathrm{g} / \mu \mathrm{l}$ and antibiotic tested standard discs were placed on the inoculated agar surface. Petri dishes were allowed to stand for $30 \mathrm{~min}$ at room temperature before incubation at $37^{\circ} \mathrm{C}$ for $24 \mathrm{~h}$. The effect of the ethanolic extract was reflected by the appearance around the disc with a transparent circular zone corresponding to the absence of growth. The diameter of inhibition zone was measured in $\mathrm{mm}$. The larger the diameter of the area the more susceptible the strain $[22,23]$.

\section{Statistical analysis}

Three replicates of each sample concentration were used for statistical analysis by the Graphpad Prism version 5. Results with $\mathrm{P}<0.05$ were considered to be significant.

\section{RESULTS}

\section{Phytochemical screening}

The preliminary phytochemical screening is a means of evaluating the potential phyto compounds in the leaf extract of Millingtonia hortensis. Phytochemical characterizations of solvent extracts of $M$. hortensis are presented in (table 1). The phytochemical screening revealed the strong presence of carbohydrates, tannins, saponins, flavonoids, alkaloids, betacyanins, phenols and coumarins.

\section{DPPH radical scavenging activity}

DPPH radical scavenging activity of methanol, petroleum ether, chloroform, ethanol, aqueous extracts of $M$. hortensis leaf are shown in (fig. 3). Among the solvent tested, ethanol extract exhibited highest DPPH radical scavenging activity. At $70 \mu \mathrm{g} / \mathrm{ml}$ concentration of ethanol leaf extract showed nearly $80 \%$ scavenging activity of DPPH.

\section{Superoxide radical scavenging activity}

In this assays, the liberated radicals are scavenged and the inhibition was estimated for different solvent extracts of $M$. hortensis leaf extracts (fig. 4). In the presence of an antioxidant, $70 \%$ inhibition was observed in ethanol extract at $100 \mu \mathrm{g} / \mathrm{ml}$ concentration followed by methanol extract.

\section{GC-MS analysis}

The composition and identification of the compounds present in the ethanol leaf extracts of $M$. hortensis by GC-MS analysis shown in (table 2). The active principles with their retention time (RT), molecular formula, molecular weight (MW) are presented in (fig. 4). The main constituents were Heptadecanoic acid, 15-methyl-methyl ester, Oleic Acid and Estra-1,3,5(10)-trien-17a-ol.

\section{Antibacterial assay}

The antimicrobial activity of the investigated extracts against five bacterial used by disc diffusion method was shown in (table 3). The obtained results of $M$. hortensis ethanolic leaf extract revealed the maximum diameter zone of $13 \mathrm{~mm}$ in Pseudomona aeroginosa and minimum diameter zone of $6.1 \mathrm{~mm}$ in Salmonella typhi, other microbes like Klebsiella pneumonia, Citrobactor brakii and Escherichia coli showed minimum inhibition zone concentration diameter ranging from $10 \mu \mathrm{g} / \mu \mathrm{l}$ to $25 \mu \mathrm{g} / \mu \mathrm{l}$. But almost all the microbes exhibited higher diameter zone at the concentration of 30 $\mu \mathrm{g} / \mu \mathrm{l}$ nearer to standard inhibition zones. Antibacterial activity of $M$. hortensis leaf ethanol extract was assayed in vitro by disc diffusion method against microbes of E. coli and P. aeroginosa, K. pneumonia, S. typhi, C. braakii. The given (table 3). Shows the microbial growth inhibition of ethanolic leaf extracts of $M$. hortensis. Among the varying concentration of leaf extracts, higher concentration exhibited maximum antibacterial activity against the two clinical isolates. table 3 shows the zone of inhibition formed by the extracts against the bacterial strains on Muller Hinton agar. The sequence of antibacterial activity of leaf extract against E. coli exhibited no activity at $10 \mu \mathrm{l}$ but produced $8.1 \mathrm{~mm}$ and $13 \mathrm{~mm}$ zones of inhibition observed at $30 \mu \mathrm{l}$, whereas the plant extracts showed no activity against $K$. pneumonia at $10 \mu \mathrm{l}$ but produced $8.2 \mathrm{~mm}$ inhibition zone in $30 \mu \mathrm{l}$ concentration (table 3). Thus antibacterial activity was observed at varying degrees with the difference in concentration. Higher concentration of the leaf extract shows highest antibacterial activity. The results obtained might be considered sufficient for further studies for isolation and identification of active principle and for the evaluation of possible antimicrobial activity 


\section{DISCUSSION}

The phytochemical constituents of the different solvent extracts of $M$. hortensis were exhibited high antioxidant and antibacterial activity.

The result of DPPH scavenging activity indicates that the plant has bioactivity. This suggests that the plant extract contain compounds that are capable of donating hydrogen to a free radical in order to remove an odd electron which is responsible for free radical's reactivity [24]. Among four extracts, ethanol extract showed maximum scavenging activity followed by the aqueous extract. The DPPH radical scavenging activity may be due to the presence of various phytochemicals including polyphenols and flavonoids in $M$. hortensis leaf extracts.

Superoxide anions are the most common free radicals in vitro and are generated in a variety of biological systems either by autooxidation processes or by enzymes. The concentration of superoxide increases under conditions of oxidative stress and related situations [25]. Moreover, superoxide anions produce other kinds of cell damaging free radicals and oxidizing agents [26]. Therefore $M$. hortensis leaf was undertaken to test whether it has a scavenging activity of superoxide anions. $70 \%$ inhibition was recorded in ethanolic leaf extract. The results clearly indicate that $M$. hortensis leaf extracts have noticeable effect as scavenging superoxide radical.

In the present study, phytoconstituents like 4,6,Heptadien-3one,1,7,-diphenyl, 7-Octadecenal, 9-Oxabicyclo[3.3.1]nonane-2,6diol, Estra-1,3,5(10)-trien-17a-ol, Pentadecanoic acid,14methylmethyl ester, 8-Octadecenoic acid,methyl ester, Oleic Acid, Heptadecanoic acid, 15-methyl-ethyl ester, 4-Piperidineacetic acid,1-acetyl-5-Ethyl-2[3-[2-hydroxyethyl]-1H-Indol-2-yl]-a-methylmethyl ester, Aspidofractinine-3-methanol (2a,3a,5a), Octadecanoic acid,2[2-hydroxy ethoxy] ethyl ester, Octadecanoic acid,2[2-hydroxy ethoxy] ethyl ester, Z-7-Pentadecenol were identified from ethanol extract of $M$. hortensis by using a gas chromatography-mass spectrography. The basic structural features of phenolic compounds is an aromatic ring bearing methyl esters, hexadecanoic acid, eicosanoic acid, ethyl ester with more hydroxyl groups [27]. Phenolic compounds are known as powerful chain breaking antioxidants and they are very important plant constituents because of their scavenging ability, which is due to their hydroxyl groups [28]. Flavonoids are a group of polyphenolic compounds, which exhibit several biological effects such as anti-inflammatory, antihepatotoxic, anti ulcer, antiallergic, antiviral and anticancer activities [29] Phytochemical components are known to produce therapeutic activity like antibacterial, antifungal and antioxidant etc [30].

The earlier study reveals that the ethanol leaf extracts of $A$ squamosa were more active against the clinical bacterial pathogens viz. E. coli and $P$. aeroginosa the antibacterial activity may be due to the presence of different phyto chemical compounds in the leaf extract including essential oils, flavonoids, terpenoids and other components which are classified as active antimicrobial compounds.
The results of the study supports to a certain degree, the use of traditional medicinal plants in human and animal disease therapy and reinforce the concept of ethno botanical approach in screening plants as potential sources of bioactive substances [31]. The aqueous extract generally exhibits a high degree of antibacterial activity which seems to confirm the traditional therapeutic claims of this plant [32].

These biologically important Phyto-compounds exerts antimicrobial activity by using a different mechanism for example flavonoids exhibits antimicrobial, anti-inflammatory, anti-angionic, analgesic, antiallergic and antioxidant properties [33]. Ability to scavenge free radicals, lipid peroxyl radicals makes them an essential phytoconstituent which is important for prevention of ailments associated with the oxidative damage [34]. Tannins are reported to have iron deprivation property, astringent in nature and exhibit antimicrobial activity [35]. Saponins have also been reported to possess antimicrobial activity due to their detergent like nature as they can cause leakage in the membrane by interacting with proteins and certain enzymes from the bacterial cell [36-38]. Alkaloids are reported to have anti-quorum sensing property [39].

\section{CONCLUSION}

The present study suggests that the leaves of the M. hortensis contains a considerable amount of Phyto-compounds like saponins, alkaloids, flavonoids and phenols which are responsible for the antioxidant and antibacterial activities. Hence, this plant may be explored as a new source for potent antimicrobial drugs of natural origin. Further studies are being carried out to isolate and purify the active principle and to evaluate its mechanism of action.

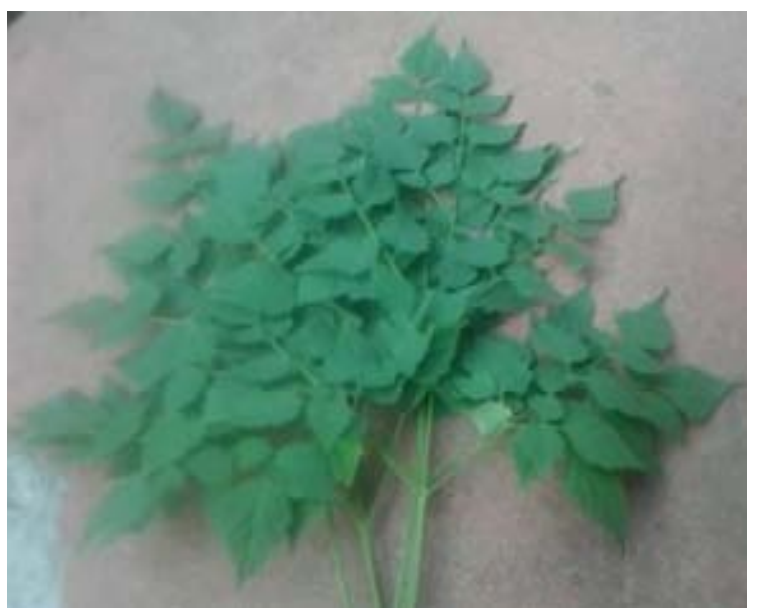

Fig. 1: Millingtonia hortensis leaves

Table 1: Phytochemical screening of leaf extracts of Millingtonia hortensis

\begin{tabular}{|c|c|c|c|c|c|c|}
\hline S. No. & Secondary metabolites & Aqueous & Ethanol & Methanol & Chloroform & Petroleum ether \\
\hline 1 & Tannins & - & +++ & + & ++ & + \\
\hline 2 & Saponin & ++ & +++ & ++ & + & - \\
\hline 3 & Flavonoids & +++ & +++ & +++ & ++ & ++ \\
\hline 4 & Alkaloids & +++ & +++ & +++ & + & ++ \\
\hline 5 & cyanins & +++ & +++ & +++ & +++ & +++ \\
\hline 6 & Quinones & + & - & - & - & ++ \\
\hline 7 & Glycosides & - & - & - & ++ & + \\
\hline 8 & Cardiac glycosides & ++ & +++ & ++ & - & - \\
\hline 9 & Terpenoids & + & - & - & - & _- \\
\hline 10 & Triterpenoids & _- & - & ++ & - & - \\
\hline 11 & Phenols & ++ & +++ & +++ & + & ++ \\
\hline 12 & Coumarins & +++ & +++ & +++ & ++ & +++ \\
\hline 13 & Acids & ++ & ++ & + & ++ & ++ \\
\hline 14 & Proteins & - & - & - & - & - \\
\hline 15 & Steroids & + & +++ & ++ & ++ & - \\
\hline
\end{tabular}

+++Strongly positive++Positive, +Trace-Not detected 


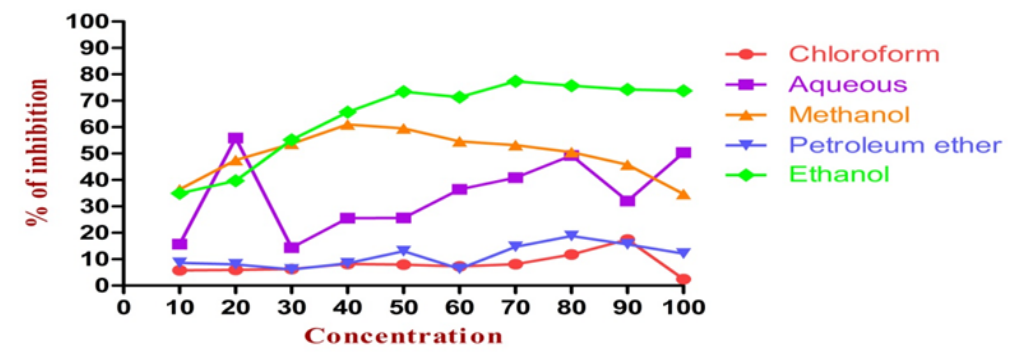

Fig. 2: Antioxidant assay-DPPH radical scavenging activity of leaf extracts of $M$. hortensis

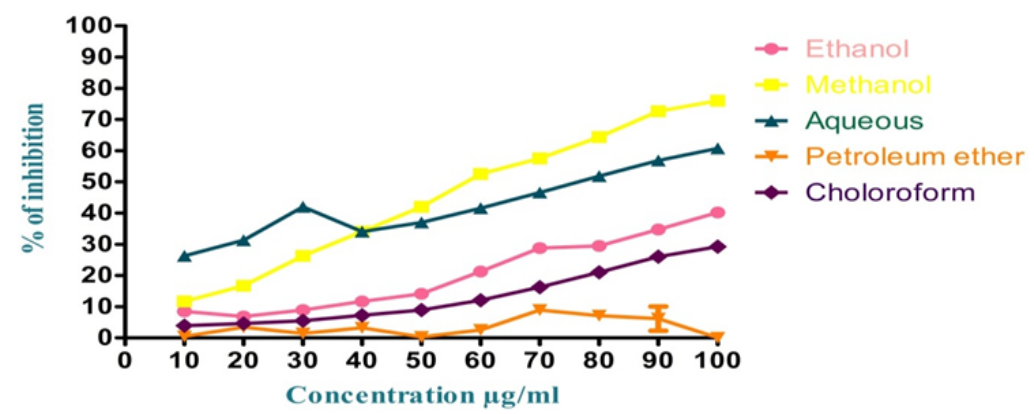

Fig. 3: Antioxidant assay superoxide radical scavenging activity of leaf extracts of $M$. hortensis

Table 2: Gas chromatography mass spectrometry of ethanol leaf extracts of $M$. hortensis

\begin{tabular}{|c|c|c|c|c|c|}
\hline $\begin{array}{l}\text { S. } \\
\text { No. }\end{array}$ & $\begin{array}{l}\text { Retention } \\
\text { time }\end{array}$ & Compound & $\begin{array}{l}\text { Molecular } \\
\text { formula }\end{array}$ & $\begin{array}{l}\text { Molecular } \\
\text { weight }\end{array}$ & $\begin{array}{l}\text { Peak } \\
\text { area \% }\end{array}$ \\
\hline 1 & 11.6 & 4,6,Heptadien-3-one,1,7,-diphenyl & $\mathrm{C}_{19} \mathrm{H}_{18} \mathrm{O}$ & 262.34 & 6.75 \\
\hline 2 & 12.7 & 7-Octadecenal & $\mathrm{C}_{18} \mathrm{H}_{34} \mathrm{O}$ & 266.46 & 7.48 \\
\hline 3 & 13.67 & 9-Oxabicyclo[3.3.1]nonane-2,6-diol & $\mathrm{C}_{8} \mathrm{H}_{14} \mathrm{O} 3$ & 158.19 & 7.26 \\
\hline 4 & 14.05 & Estra-1,3,5(10)-trien-17a-ol & $\mathrm{C}_{21} \mathrm{H}_{26} \mathrm{O}_{2}$ & 310.42 & 11.82 \\
\hline 5 & 15.73 & Pentadecanoic acid,14methyl-methyl ester & $\mathrm{C}_{17} \mathrm{H}_{34} \mathrm{O}_{2}$ & 270.45 & 4.8 \\
\hline 6 & 17.13 & 8-Octadecenoic acid,methyl ester & $\mathrm{C}_{19} \mathrm{H}_{36} \mathrm{O}_{2}$ & 296.48 & 5.8 \\
\hline 7 & 17.83 & Oleic Acid & $\mathrm{C}_{19} \mathrm{H}_{38} \mathrm{O}_{2}$ & 298.5 & 30.09 \\
\hline 8 & 18.9 & Heptadecanoic acid, 15-methyl-ethyl ester & $\mathrm{C}_{18} \mathrm{H}_{34} \mathrm{O}_{2}$ & 282.46 & 13.04 \\
\hline 9 & 19.12 & $\begin{array}{l}\text { 4-Piperidineacetic acid,1-acetyl-5-Ethyl-2[3-[2-hydroxyethyl]-1H- } \\
\text { Indol-2-yl]-a-methyl-methyl ester }\end{array}$ & $\mathrm{C}_{20} \mathrm{H}_{40} \mathrm{O}_{2}$ & 312.53 & 2.2 \\
\hline 10 & 19.52 & Aspidofractinine-3-methanol $(2 \mathrm{a}, 3 \mathrm{a}, 5 \mathrm{a})$ & $\mathrm{C}_{23} \mathrm{H}_{32} \mathrm{~N}_{2} \mathrm{O}_{4}$ & 400.51 & 3.9 \\
\hline 11 & 19.75 & Octadecanoic acid,2 [2-hydroxy ethoxy] ethyl ester & $\mathrm{C}_{20} \mathrm{H}_{26} \mathrm{~N}_{2} \mathrm{O}_{4}$ & 310 & 3.7 \\
\hline 12 & 23.21 & Octadecanoic acid,2 [2-hydroxy ethoxy] ethyl ester & $\mathrm{C}_{22} \mathrm{H}_{44} \mathrm{O}_{4}$ & 372.58 & 2.2 \\
\hline 13 & 22.58 & Z-7-Pentadecenol & $\mathrm{C}_{16} \mathrm{H}_{34}$ & 224.44 & 1.2 \\
\hline
\end{tabular}

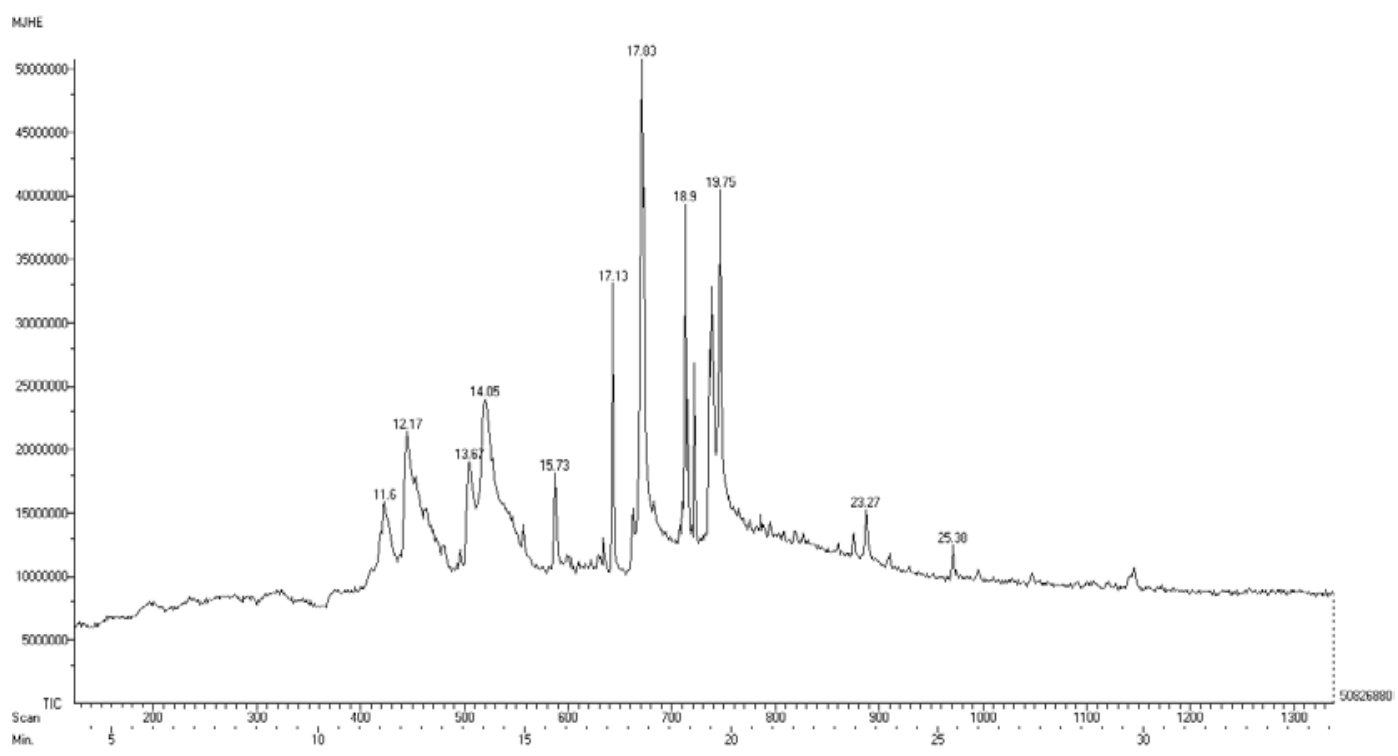

Fig. 4: Gas chromatography mass spectrometry of ethanol leaf extracts of $M$. hortensis 
Table 3: Antibacterial activity of Millingtonia hortensis ethanolic extract

\begin{tabular}{|c|c|c|c|c|c|c|}
\hline $\begin{array}{l}\text { S. } \\
\text { No. }\end{array}$ & $\begin{array}{l}\text { Concentration } \\
\text { of sample } \\
\mu \mathrm{g} / \mu \mathrm{l}\end{array}$ & $\begin{array}{l}\text { E. coli } \\
\text { zone of inhibition } \\
\text { mm }\end{array}$ & $\begin{array}{l}\text { Salmonella } \\
\text { zone of inhibition } \\
\text { mm }\end{array}$ & $\begin{array}{l}\text { Citrobacter } \\
\text { zone of inhibition } \\
\text { mm }\end{array}$ & $\begin{array}{l}\text { Klebsiela zone of } \\
\text { inhibition } \mathrm{mm}\end{array}$ & $\begin{array}{l}\text { Pseudomonas } \\
\text { zone of inhibition } \\
\text { mm }\end{array}$ \\
\hline 1 & 10 & - & 6.1 & 6.2 & - & 6.3 \\
\hline 2 & 15 & 6.8 & 6.3 & 6.3 & 6.5 & 6.7 \\
\hline 3 & 20 & 7.2 & 6.4 & 6.5 & 6.7 & 7.3 \\
\hline 4 & 25 & 7.6 & 6.5 & 9.4 & 6.8 & 10.6 \\
\hline 5 & 30 & 8.1 & 9.3 & 9.8 & 8.2 & 13 \\
\hline 6 & Std $30 \mu \mathrm{g} / \mu \mathrm{l}$ & 13 & 14 & 18 & 14 & 11 \\
\hline
\end{tabular}
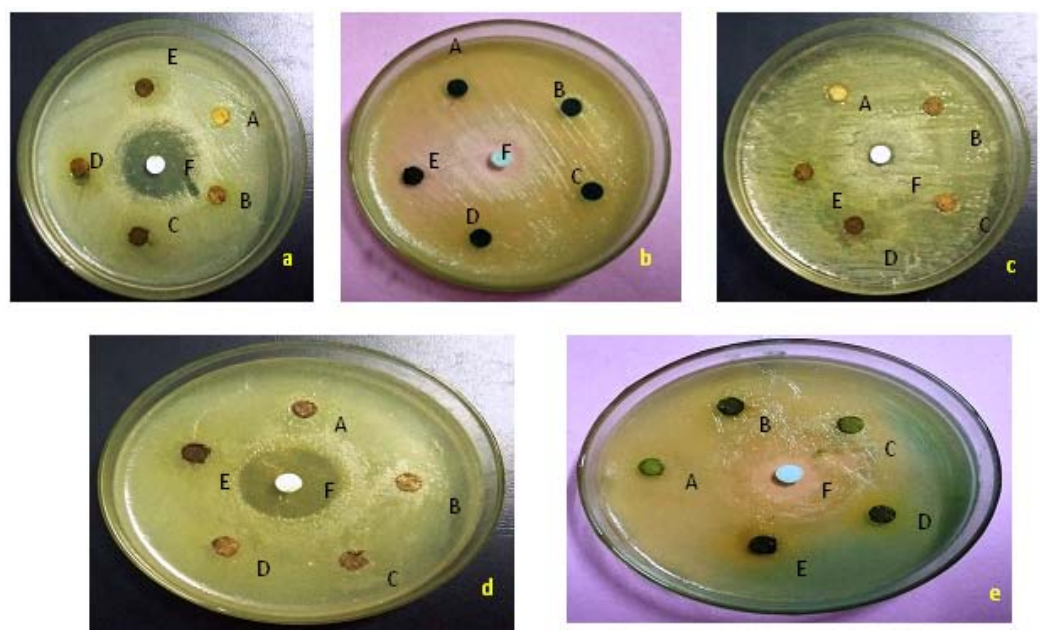

Fig. 5: Antimicrobial activity of leaf extracts of Millingtonia hortensis by disc diffusion method, i.) Escherichia coli, ii) Salmonella typhi, iii) Citrobacter braakii, iv) Klebsiella pneumonia, v) Pseudomonas aeroginosa, A-10 $\mu \mathrm{g} / \mu \mathrm{l}, \mathrm{B}-15 \mu \mathrm{g} / \mu \mathrm{l}, \mathrm{C}-20 \mu \mathrm{g} / \mu \mathrm{l}, \mathrm{D}-25 \mu \mathrm{g} / \mu \mathrm{l}, \mathrm{E}-25 \mu \mathrm{g} / \mu \mathrm{l}, \mathrm{F}-\mathrm{Std}$ $30 \mu \mathrm{g} / \mu \mathrm{l}$

\section{CONFLICT OF INTERESTS}

Declare none

\section{REFERENCES}

1. Maher G, Enas A, Hanee A, Maisa A, Jafar E, Ismael 0 . Antimicrobial activity of crude extracts of some plant leaves. Res J Microbiol 2012;7:1-10.

2. Kabra AO, Bairagi GB, Mahamuni AS, Wanare RS. In vitro antimicrobial activity and phytochemical analysis of the peels of Citrus medica L. Int J Res Pharm Biomed Sci 2012;3:34-7.

3. Krishna Raju AV, Rao TVN, Sundararaju D. Assessment of bioactivity of Indian medicinal plants using brine shrimp (Artemia salina) lethality. Int J Appl Sci Eng 2005;2:125-34.

4. Chanda S, Dave R. In vitro models for antioxidant activity evaluation and some medicinal plants possessing antioxidant properties: an overview. Afr J Microbiol 2009;3:981-96.

5. Joseph JA, Shukitt-Hale B, Denisova NA, Bielinski D, Martin A, McEwen JJ. Reversals of age-related declines in neuronal signal transduction congnitive and motor behavioural deficits with blueberry, spinach or strawberry dietary supplementation. J Neurol Sci 1999;19:8114-21.

6. Gordon MH, Weng XC. Antioxidants properties of extracts from Tanshen (Salvia militiorrhiza Bunge). Food Chem 1992;44:119-22.

7. Gu LW, Weng XC. Antioxidant activity and components of Salvia plebeian R, Br-a chineses herb. Food Chem 2001;73:299-305.

8. Pyo YH, Lee TC, Logendrac H, Rosen RT. Antioxidant activity and phenolic compounds of Swiss Chard (Beta vulgaris subspecies cycla) extracts. Food Chem 2004;85:19-26.

9. Branen AL. Toxicology and biochemistry of butylated hydroxyl anisole and butylated hydroxyl toluene. J Am Oil Chem Soc 1975;52:59-63.

10. Grice HC. Safety evaluation of butylated hydroxyl toluene (BHT) in the liver, lung and gastro intestinal tract. Food Chem Toxicol 1986;24:1127-30.
11. Wichi HP. Enhanced tumor development by butylated hydroxyl anisole (BHA) from the perspective of effect on forestomach and oesophageal squamous epithelium. Food Chem Toxicol 1988;26:717-23.

12. Rice-Evans C. Flavonoids and isoflavones: absorption metabolism and bioactivity. Free Rad Biol Med 2004;36:827-8.

13. Chanda S, Rakholiya K. Combination therapy: synergism between natural plant extracts and antibiotics against infectious diseases. Microbiol Book Series; 2011. p. 520-9.

14. Harishchandra MR, Rajan PR, Singh Satyendrakumar RP. Study of the krimighna effect of nimba (Azadiracta indica A. Juss.) Patra as rakshoghna dhoopan by culture and sensitivity method W. S. R. to pyogenic bacteria. Int Res J Pharm 2012;3:142-6.

15. Silva MSP, Brandao DO, Chaves TP, Filho ALNF, Costa EMDB, Santos VL. Study bioprospecting of medicinal plant extracts of the semiarid Northeast: contribution to the control of oral microorganisms. J Evidence-Based Complementary Altern Med 2012;1-6. http://dx.doi.org/10.1155/2012/681207

16. Tansuwanwong S, Yamamoto H, Imai K, Vinitketkumnuen U. Antiproliferation and apoptosis on RKO colon cancer by Millingtonia hortensis. Plants Foods Hum Nutr 2009;64:11-7.

17. Sharma M, Puri S, Sharma PD. Antifungal activity of Millingtonia hortensis, Indian J Pharm Sci 2007;69:599-601.

18. Harbourne JB. Phytochemical methods. Chapman and Hall, London; 1998. p. 6.

19. Blois MS. Antioxidant determinations by the use of a stable free radical. Nature 1958;181:1199-200.

20. Nuno Rainha, Elisabete Lima, Jose Baptista, Carolina Rodrigues. Antioxidant properties, total phenolic, total carotenoid and chlorophyll content of anatomical parts of Hypericum foliosum. J Med Plants Res 2011;5:1930-40.

21. Lesueur D, de Rocca Serra D, Bighelli A, Hoi TM, Ban NK, Thai $\mathrm{TH}$, et al. Chemical composition and antibacterial activity of essential oil of Michelia faveolata meryll ex-dandy from vietnam. Flavour Fragr J 2007;22:317-21. 
22. Fadila Moussaoui, Tajelmolk Alaoui. Evaluation of antibacterial activity and the synergistic effect between antibiotic and the essential oils of some medicinal plants. Asian Pac J Trop Biomed 2016;6:32-7.

23. Choi YM, Noh DO, Cho SY, Suh HJ, Kim KM, Kim JM. Antioxidant and antimicrobial activities of propolis from several regions of Korea. LWT Food Sci Technol 2006;39:756-61.

24. Dharani MB, Sumathi S, Sivaprabha J, Padma PR. In vitro antioxidant potential of Prosopis cineraria. J Nat Prod Pant Resour 2011;1:26-32

25. Lee JC, Kim Hr, Kim J, Jang ys. Antioxidant property of an ethanol extract of the stem of opuntia ficus-indica var. saboten. J Agric Food Chem 2002;50:6490-5496.

26. $\mathrm{Hu} \mathrm{C}$, Kitts DD. Studies on the antioxidant activity of Echinacea root extract. J Agric Food Chem 2000;48:1466-72.

27. Chirinos R, Betalleluz-Pallardel I, Huaman A, Arbizu C, Pedreschi R, Campos D. HPLC-DAD characterization of phenolic compounds from Andean oca (Oxalis tuberose Mol.) tubers and their contribution to the antioxidant capacity. Food Chem 2009;113: 1243-51.

28. Shahidi F, Wanasundra PKJPD. Phenolics antioxidants critical reviews. Food Sci Nutr 1992;32:67-103.

29. Umamaheswari M, Chatterjee TK. In vitro antioxidant activities of the fractions of Coccinia grandis L. leaf extract. Afr J Tradit Complementary Altern Med 2008;5:61-73.

30. Sahoo AM, Chakraborti CK, Nayak S, Kayal S. Correlation between phytochemical screening and in vitro antibacterial activity study of Rosa indica leaves. Int J Res Ayurveda Pharm 2011;2:1595-7.

31. Valsaraj R, Pushpangathan P, Smitt UW. Antimicrobial screening of selected medicinal plants from India. J Ethnopharmacol 1997;58:75-83.

32. Perumal Samy R, Ignachimuthu S, Sen A. Screening of 34 Indian medicinal plants for antibacterial properties. J Ethnol Pharmacol 1998;62:173-82.
33. Damle M. Glycyrrhiza glabra (Liquorice)-a potent medicinal herb. Int J Herb Med 2014;2:132-6.

34. Chopra PKPG, Saraf BD, Inam F, Deo SS. Antimicrobial and antioxidant activities of methanol extract roots of glycyrrhiza glabra and HPLC analysis. Int J Pharm Pharm Sci 2013;5:15760.

35. Sharma V, Agarwal RC, Pandey S. Phytochemical screening and determination of anti-bacterial and antioxidant potential of Glycyrrhiza glabra root extracts. J Environ Res Dev 2013;7:1552-8

36. Dharmananda S. Gallnuts and the uses of tannins in Chinese medicine. In: Proceedings of Institute for Traditional Medicine, Portland, OR, USA; 2003.

37. Noboti T, Miura K, Wu DJ, Lois A, Takabayashi K, Carson DA. Deletions of the cyclin-dependent kinase-4 inhibitor gene in multiple human cancers. Nature 1994;368:753-6.

38. Ganguly T, Sainis KB. Inhibition of cellular immune responses by Tylophora indica in experimental models. Phytomedicine 2001;8:348-55.

39. Tamil SA, Dinesh MG, Satyan RS, Chandrasekaran B, Rose C. Leaf and seed extracts of Bixa orellana L. exerts antimicrobial activity against bacterial pathogens. J Appl Pharm Sci 2011;1:116-20.

40. Chakotiya AS, Chawla R, Tomar M, Thakur P, Goel R, Narula A et al. In silico herbal bioprospection targeting multi-drug resistant Pseudomonas aeruginosa. Int J Interdiscip Multidiscip Stud 2014;2:163-76.

\section{How to cite this article}

- Janaki A, Kaleena PK, Elumalai D, Hemalatha P, Babu M, Velu K, Sudha Ravi. Phytochemical screening, antioxidant and antibacterial activities of Millingtonia hortensis (L). Int J Curr Pharm Res 2017;9(5):162-167. 